\title{
Results of Curative Radiotherapy Alone in Patients with Uterine Cervical Carcinomas
}

Taek-Keun Nam, M.D. ${ }^{1}$, Byung-Sik Nah, M.D. ${ }^{2}$, Sung-Ja Ahn, M.D. ${ }^{2}$, Woong-Ki Chung, M.D. ${ }^{2}$, Ho-Seon Choi, M.D. ${ }^{3}$ and Yoon-Kyeong Oh, M.D. ${ }^{1}$

${ }^{1}$ Department of Radiation Oncology, Chosun University Medical School, ${ }^{2}$ Department of Radiation Oncology, ${ }^{3}$ Department of Gynecology and Obstetrics, Chonnam University Medical School, Gwangju, Korea

Purpose: To evaluate the role of curative radiotherapy alone in the treatment of uterine cervical carcinomas, by a retrospective analysis with respects to survival and pelvic control, and to find any risk factors of failure

Materials and Methods: Between Jan. 1990 and Dec. 1995 , a total of 187 patients, diagnosed with uterine cervical carcinomas in FIGO stages greater than IA, were treated by curative radiotherapy alone with no chemo. therapy. The ages of the patients ranged from 26 to 80 years, with a median of 60 years. The number of patients diagnosed with squamous cell carcinomas were 183 $(97.9 \%)$. The number of patients with FIGO stage IB1, IB2, IIA, IIB, IIIA, IIIB and IVA were $61(32.6 \%), 7(3.7 \%), 43$ $(23.0 \%), 62(33.3 \%), 3(1.6 \%), 7(3.7 \%)$ and $4(2.1 \%)$, respectively. External radiotherapy was performed with 6 MV or 10 MV X-rays, with a dose range of $19.8 \mathrm{~Gy} \sim 50.4$ Gy (median; 30.6), to whole pelvis. Intracavitary radiation (ICR) was then performed using a high-dose rate remote controlled afterloader with radioisotopes of C0-60 and Cs-137. The fraction size of the ICR was 5 Gy twice a week, and was delivered up to total doses of $10 \mathrm{~Gy} \sim$ 55 Gy (median; 40). After the ICR, additional pelvic external radiotherapy with midline shielding width of $4 \mathrm{~cm}$

\section{서 론}

자궁경부암에서 방사선치료는 조기 병기의 경우 근치적 역할을 수행하고 진행된 병기에서도 다른 종양에 비해 비 교적 높은 종양제어를 얻을 수 있다. 방사선 치료는 통상 외부방사선 치료와 자궁강내조사로 이루어지는데, 특히 자 궁강내조사의 추가는 종양제어를 위해서 필수적인 치료항 목으로 잘 알려져 있다(1). 자궁강내조사의 선원에 따라 전

Correspondence: Taek-Keun Nam, Department of Radiation Oncology, Chosun University Medical School, 588 Seoseok-dong, Dong-gu, Gwangju 501-717, Korea. (Tel) 062-220-3245, (Fax) 062-2277757, (E-mail) tknam@ @hosun.ac.kr

Received July 15, 2002, Accepted September 17, 2002 was performed with the dose range of $0 \sim 30.6 \mathrm{~Gy}$ (median; 19.8), and the resultant total doses of $A$ points ranged between $49.8 \mathrm{~Gy}$ and $86.0 \mathrm{~Gy}$ (median; 70.6).

Results: The five-year overall survival rates of FIGO IB1, IB2, IIA, IIB, III and IVA were 88.3\%, 83.3\%, 86.1\%, 65.2\%, $60.0 \%$ and $50.0 \%$, respectively $(p=0.005)$. The pelvic control rates of each stage were $90.1 \%, 85.7 \%, 86.1 \%$, $69.4 \%, 68.6 \%$ and $50.0 \%$, respectively $(p=0.03)$. From the multivariate analysis, the radiation response and tumor diameter were found to be significant factors affecting the overall survival. The significant factors influencing pelvic control were the radiation response and pre-treatment hemoglobin level.

Conclusion: The radiation response and tumor diameter were significant factors affecting survival, so patients with tumor diameters greater than $4 \mathrm{~cm}$ should be considered for a combined modality, such as concurrent chemoradiotherapy. (Cancer Research and Treatment 2002;34:365371)

Key Words: Uterine cervical carcinoma, Radiotherapy, Survival, Pelvic control, Prognostic factor

통적인 저선량률 방식과 고선량률 방식이 있는데 최근에는 외래 통원치료가 가능하고 시술자의 피폭의 위험이 없는 등의 장점으로 인해 고선량률 방식이 증가하고 있다. 강내 조사의 이러한 두 가지 조사방법에 있어서 종양제어율, 생 존율 및 합병증의 발생률은 대체로 차이가 없는 것으로 알 려져 있다(2). 그러나 진행된 병기의 경우나 재발의 위험이 높은 환자의 경우, 방사선 단독치료의 성적을 높이기 위한 목적으로 동시적 항암화학 방사선요법이 시도되었고 최근 의 몇 가지 전향적 연구에서 종양제어율 및 생존율의 유의 한 상승이 보고된 이후 현재 표준화된 치료로 정립되고 있 다(3 6). 그러나 적극적인 동시적 항암화학 방사선요법은 이로 인한 잠재적인 합병증의 가능성이 높고 의료비 상승 등의 문제가 있으며 따라서 이러한 치료의 적응증을 분명 하게 규정할 필요가 있다. 
이에 본 연구는 과거 방사선 단독치료만으로 치료했던 환자를 대상으로 종양제어 및 생존율 등을 후향적으로 분 석하여 치료실패의 고위험인자를 파악하고 이를 토대로 동 시적 항암화학 방사선요법 등 더 적극적인 치료가 필요한 적응증을 정립하는 데 활용하고자 하였다.

\section{대상 및 방법}

\section{1) 환자 특성}

1990년 1월부터 1995년 12월까지 자궁경부암 FIGO 병기 (7) IB1 이상으로 진단되어 근치적 목적의 방사선 단독치료를 받은 환자는 209 명이었다. 병기결정을 위해 골반강 내진 등 이학적 검사, 전혈구검사, 흉부 방사선촬영, 정맥성 신우조영 술, 방광경 및 직장경검사 등을 시행하였고 필요에 따라 컴퓨 터 단층촬영 또는 자기공명영상 등을 참고하였다. 전체 209 명의 환자 중 생사 및 종양제어 여부의 확인이 가능했던 187 명 $(89.5 \%)$ 의 환자를 본 연구의 대상으로 하였다. 환자의 연령 분포는 26 84세였고 중앙값은 60 세였다. FIGO 병기 IB1, $\mathrm{IB} 2, \mathrm{IIA}, \mathrm{IIB}, \mathrm{IIIA}, \mathrm{IIIB}, \mathrm{IVA}$ 의 환자분포는 각각 61 (32.6\%), 7 (3.7\%), 43 (23.0\%), 62 (33.3\%), 3 (1.6\%), 7 (3.7\%), 4 (2.1\%) 이었다. 병리조직소견은 편평세포암이 183 명(97.9\%), 선암이 3 명 $(1.6 \%)$, 선편평세포암이 한 명 $(0.5 \%)$ 이었다.

\section{2) 방사선치료}

외부방사선치료로서 $6 \mathrm{MV}$ 또는 $10 \mathrm{MV} \mathrm{X}$-선을 이용하여 전골반강에 19.8 $50.4 \mathrm{~Gy}$ (중앙값; 30.6)를 조사하고 강내 치료 이후에는 $4 \mathrm{~cm}$ 너비의 중앙차폐를 시행하여 골반강에 0 30.6 Gy (중앙값; 19.8)를 조사하였고 필요 시 좌우측 $\mathrm{B}$ 점에 추가 조사하여 총외부방사선량 $30.6 \sim 77.4 \mathrm{~Gy}$ (중앙 값; 50.4)를 조사하였다. 조사방법은 203명(97.1\%)이 4문 박 스형 조사야(일일 2문 조사)로, 4명(1.9\%)은 전후방 2문 조 사야로, 2 명(1.0\%)은 대동맥주위림프절 부위를 포함하여 전 후방 2문 조사야로 각각 시행하였다. 강내조사는 Co-60과 Cs-137을 선원으로 하는 고선량률의 원격조정 강내조사기 (Buchler ${ }^{\circledR}$, Germany)로서 한 개의 탄뎀(tandem)과 한 쌍의 난원체(ovoid)로 조합된 3 채널방식으로 조사하였고, 일회 $5 \mathrm{~Gy}$ 씩 주 2회로 10 55 Gy (중앙값; 40.0)를 조사하여 외부 방사선조사와 강내조사를 합한 총 $\mathrm{A}$ 점의 방사선량이 49.8 $86.0 \mathrm{~Gy}$ (중앙값; 70.6)가 되게 치료하였다. 전체 환자의 방 사선 치료기간은 49 122일(중앙값; 78일)이었다.

\section{3) 추적관찰 및 통계}

추적관찰은 방사선치료 후 2 년간은 매 3 개월, 그 이후는 매 6개월마다 시행함을 원칙으로 하였고, 종양의 관해 정도
의 평가는 치료 후 6개월까지로 하였다. 전체 환자의 추적 관찰기간의 범위는 3 128개월(중앙값; 72 개월)이었다. 생 존기간은 방사선치료 시작일부터 사망 또는 최후 추적일까 지 계산하였고, 무병생존기간은 방사선치료 시작일부터 종 양의 국소재발이나 원격전이 발견일 또는 최후 추적일까지 계산하였으며 자궁경부암 이외의 원인으로 사망한 경우는 검열예로 처리하였다. 골반제어의 정의는 원발병소와 골반 림프절을 포함한 골반부에서의 종양제어로 규정하였다. 만기 합병증의 발생정도는 RTOG/EORTC의 분류체계(8)에 의하여 기술하였다. 생존율 및 누적 종양제어율, 합병증 발 생률의 산출은 Kaplan-Meier 방법으로 하였고 각 군 간의 생존율 및 누적 종양제어율의 차이의 검증은 $\log \operatorname{rank}$ test를 이용하였다. 종양제어율 및 생존율에 영향을 미치는 인자 들에 대한 다변량 검증은 Cox proportional hazards model을 이 용하였고 이의 모든 통계적 처리는 SPSS (statistical package for the social science) 프로그램을 이용하였다.

\section{결 과}

\section{1) 병기별 생존율 및 종양제어율}

전체 환자의 5년 생존율은 $77.7 \%$ 이었다. FIGO 병기 IB1, IB2, IIA, IIB, III, IVA의 5년 생존율은 각각 $88.3 \%, 83.3 \%$, $86.1 \%, 65.2 \%, 60.0 \%, 50.0 \%$ 이었다(p=0.005, Fig. 1). 전체 환 자의 5년 무병생존율은 $73.8 \%$ 이었다. 상기의 FIGO 병기에 따른 5년 무병생존율은 각각 $86.9 \%, 71.4 \%, 81.4 \%, 61.1 \%$, $60.0 \%, 25.0 \%$ 이었다( $\mathrm{p}=0.001)$. 전체 환자의 골반제어율은 $80.3 \%$ 이었다. 병기별 골반제어율은 각각 $90.1 \%, 85.7 \%, 86.1 \%$, $69.4 \%, 68.6 \%, 50.0 \%$ 이었다(p=0.03). 병기별 재발양상에 대

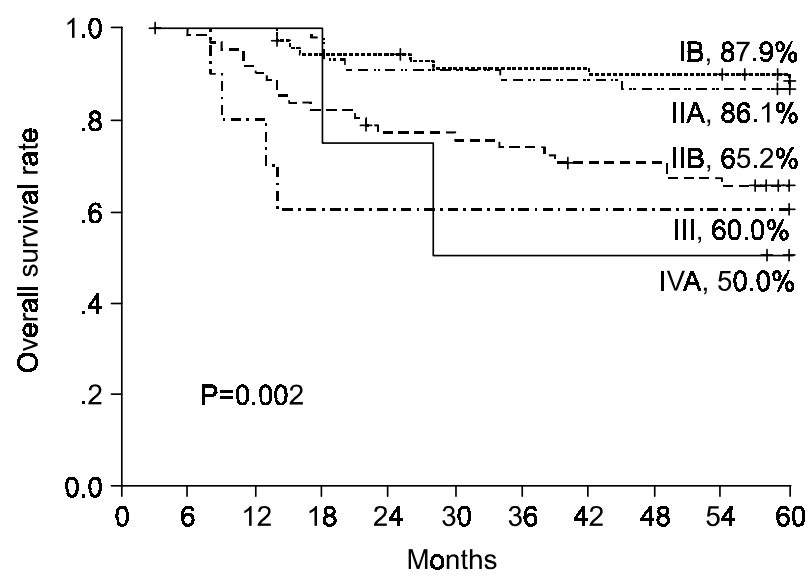

Fig. 1. 5-year overall survival curves according to the FIGO stage. Stage IB includes both IB1 and IB2, stage III represents IIIA and IIIB. 
한 분포는 Table 1에 나타나 있다. 원격전이 병소의 분포는 각각 대동맥주위 림프절전이 10 예, 골 전이 4 예, 쇄골상부 림프절전이 3 예, 간 전이 1 예, 복벽 전이 1 예, 서혜부 림프절 전이 1 예이었다.

2) 치료 전 및 치료 후 예후인자들에 대한 일변량 분석

치료 전 예후인자들로서 당뇨 유무, 고혈압 유무, 연령, $\mathrm{ECOG}$ 활동지수, 방사선학적 림프절전이 여부, 종양의 최
대직경, FIGO 병기, 종양의 형태, 조직학적 분류, 치료 전 혈색소의 농도, 치료 전 혈중 SCC (squamous cell carcinoma antigen) 농도 등 11 개 인자를 대상으로 하였고, 치료 후 예 후인자들로서는 A점 총방사선량, 방사선치료기간, 종양의 완해여부, 치료 후 혈중 SCC 농도 등 4개 인자를 대상으로 하였다. 5년 생존율에 영향을 미치는 예후인자들에 대한 일 변량분석에서는 연령, $\mathrm{ECOG}$ 활동지수, 방사선학적 림프절 전이 여부, 종양의 직경, $\mathrm{FIGO}$ 병기, 치료 전 혈중 $\mathrm{SCC}$ 농도,

Table 1. Patterns of failure according to the stage (\%)

\begin{tabular}{|c|c|c|c|c|c|c|}
\hline & IB1 & IB2 & IIA & IIB & III & IVA \\
\hline No. of patients & 61 & 7 & 43 & 62 & 10 & 4 \\
\hline Pelvic* only & $6(10)$ & $1(14)$ & $3(7)$ & $14(23)$ & $3(30)$ & $2(50)$ \\
\hline Pelvic $+\mathrm{DM}^{\dagger}$ & 0 & 0 & $3(7)$ & $4(6)$ & 0 & 0 \\
\hline Total pelvic & $6(10)$ & $1(14)$ & $6(14)$ & 18 (29) & $3(30)$ & $2(50)$ \\
\hline DM only & $2(3)$ & $1(14)$ & $2(5)$ & $6(10)$ & $1(10)$ & $1(25)$ \\
\hline Total failure & $8(13)$ & $2(29)$ & $8(19)$ & $24(39)$ & $4(40)$ & $3(75)$ \\
\hline
\end{tabular}

*pelvic failure, ${ }^{\dagger}$ distant metastasis

Table 2. Prognostic factors by univariate analysis (I)

\begin{tabular}{|c|c|c|c|c|c|c|c|c|}
\hline Factor & & $\begin{array}{l}\text { No. of } \\
\text { patients }\end{array}$ & $\begin{array}{c}5 \text {-year } \\
\left.\text { OS* }^{*} \%\right)\end{array}$ & p-value & $\begin{array}{c}5 \text {-year } \\
\operatorname{DFS}^{\dagger}(\%)\end{array}$ & p-value & $\begin{array}{c}\text { 5-year } \\
\operatorname{PDFS}^{*}(\%)\end{array}$ & p-value \\
\hline \multirow[t]{2}{*}{$\mathrm{DM}^{\S}$} & Yes & 10 & 90.0 & \multirow{2}{*}{$\mathrm{ns}^{\dagger^{+}}$} & 90.0 & \multirow[b]{2}{*}{ ns } & 100 & \multirow[b]{2}{*}{$\mathrm{ns}$} \\
\hline & No & 177 & 77.0 & & 72.9 & & 79.2 & \\
\hline \multirow[t]{2}{*}{ Hypertension } & Yes & 25 & 72.0 & \multirow{2}{*}{ ns } & 72.0 & \multirow{2}{*}{ ns } & 83.4 & \multirow{2}{*}{ ns } \\
\hline & No & 162 & 78.6 & & 74.0 & & 79.9 & \\
\hline \multirow[t]{2}{*}{ Age (years) } & $\leq 50$ & 29 & 58.6 & \multirow{2}{*}{0.006} & 55.2 & \multirow{2}{*}{0.02} & 64.0 & \multirow{2}{*}{0.02} \\
\hline & $>50$ & 158 & 81.3 & & 77.2 & & 83.2 & \\
\hline \multirow[t]{2}{*}{ ECOG PI ${ }^{\|}$} & $0 \sim 1$ & 177 & 79.9 & \multirow{2}{*}{0.0004} & 75.7 & \multirow{2}{*}{0.0005} & 81.1 & \multirow{2}{*}{ ns } \\
\hline & $2 \sim 3$ & 10 & 40.0 & & 40.0 & & 64.3 & \\
\hline \multirow[t]{3}{*}{ Radiologic $\mathrm{LN}^{\mathrm{I}}$} & None & 162 & 81.1 & \multirow{3}{*}{0.001} & 76.5 & \multirow{3}{*}{0.03} & 81.8 & \multirow{3}{*}{0.07} \\
\hline & Pelvic LN & 21 & 57.1 & & 57.1 & & 74.4 & \\
\hline & $\mathrm{PAN}^{* *}$ & 3 & 33.3 & & 33.3 & & 33.3 & \\
\hline \multirow[t]{2}{*}{ Tumor diameter } & $\leq 4 \mathrm{~cm}$ & 140 & 81.3 & \multirow{2}{*}{0.0002} & 77.8 & \multirow{2}{*}{0.0000} & 81.3 & \multirow{2}{*}{ ns } \\
\hline & $>4 \mathrm{~cm}$ & 28 & 50.4 & & 46.4 & & 72.8 & \\
\hline FIGO stage & IB1 IVA & & & 0.005 & & 0.001 & & 0.03 \\
\hline \multirow[t]{2}{*}{ Tumor shape } & Infiltrative & 96 & 76.8 & \multirow{2}{*}{ ns } & 71.8 & \multirow{2}{*}{ ns } & 80.5 & \multirow{2}{*}{ ns } \\
\hline & Other & 91 & 78.7 & & 75.8 & & 80.0 & \\
\hline \multirow[t]{2}{*}{ Pathology } & Squamous cell ca & 183 & 77.3 & \multirow{2}{*}{ ns } & 74.3 & \multirow{2}{*}{ ns } & 81.0 & \multirow{2}{*}{ ns } \\
\hline & Other & 4 & 100 & & 50.0 & & 50.0 & \\
\hline
\end{tabular}

*Overall survival, ${ }^{\dagger}$ disease-free survival, ${ }^{\ddagger}$ pelvic disease-free survival, ${ }^{\S}$ diabetes mellitus, "Eastern Cooperative Oncology Group performance index, "lymph node, $* *$ paraaortic nodes, ${ }^{\dagger+}$ statistically not significant. 
$\mathrm{A}$ 점 총방사선량, 종양의 완해여부, 치료 후 혈중 $\mathrm{SCC}$ 농도 등이 유의하였다(Table 2, 3). 5년 무병 생존율에서 영향을 미치는 유의한 인자들로는 상기 9 가지 인자와 함께 치료 전 혈색소의 농도가 추가되었다. 골반제어율에 영향을 미 치는 인자들로서는 연령, FIGO 병기, 치료 전 혈색소의 농 도, 치료 전 혈중 $\mathrm{SCC}$ 농도, 종양의 완해여부, 치료 후 혈중 $\mathrm{SCC}$ 농도 등이었다.
3) 치료 전 및 치료 후 예후인자들에 대한 다변량분석

상기 생존율 및 골반제어율에 영향을 미치는 인자들 중 일정 유의수준 이하 $(\mathrm{p}<0.10)$ 의 인자들을 대상으로 다변량 분석을 시행하였다. 공변량으로는 연령, $\mathrm{ECOG}$ 활동지수, 병기, 방사선학적 림프절 전이 여부, 종양의 크기, 치료 전 혈색소의 농도, 치료 전 $\mathrm{SCC}$ 농도 등 7 개의 치료 전 인자들과

Table 3. Prognostic factors by univariate analysis (II)

\begin{tabular}{|c|c|c|c|c|c|c|c|c|}
\hline Factor & & $\begin{array}{l}\text { No. of } \\
\text { patients }\end{array}$ & $\begin{array}{c}5 \text {-year } \\
\text { OS* }(\%)\end{array}$ & $\mathrm{p}$-value & $\begin{array}{c}5 \text {-year } \\
\operatorname{DFS}^{\dagger}(\%)\end{array}$ & $\mathrm{p}$-value & $\begin{array}{c}\text { 5-year } \\
\operatorname{PDFS}^{\ddagger}(\%)\end{array}$ & $\mathrm{p}$-value \\
\hline \multirow[t]{2}{*}{ Pre-RT ${ }^{\S}$ hemoglobin } & $\leq 12 \mathrm{~g} / \mathrm{dl}$ & 50 & 71.1 & \multirow{2}{*}{$\mathrm{ns}^{* *}$} & 62.0 & \multirow{2}{*}{0.04} & 65.0 & \multirow{2}{*}{0.002} \\
\hline & $>12 \mathrm{~g} / \mathrm{dl}$ & 131 & 79.2 & & 77.1 & & 85.2 & \\
\hline \multirow[t]{2}{*}{ Pre-RT SCC ${ }^{\|}$} & $\leq 1.5 \mathrm{ng} / \mathrm{ml}$ & 59 & 86.4 & \multirow{2}{*}{0.03} & 86.4 & \multirow{2}{*}{0.006} & 89.7 & \multirow{2}{*}{0.03} \\
\hline & $>1.5 \mathrm{ng} / \mathrm{ml}$ & 115 & 72.5 & & 66.9 & & 75.7 & \\
\hline \multirow[t]{4}{*}{ Total A point dose (Gy) } & $\leq 65$ & 8 & 75.0 & \multirow{4}{*}{0.01} & 75.0 & \multirow{4}{*}{0.002} & 75.0 & \multirow{4}{*}{ ns } \\
\hline & $65 \sim 70$ & 19 & 57.9 & & 47.4 & & 67.7 & \\
\hline & $70 \sim 75$ & 148 & 82.2 & & 78.4 & & 83.4 & \\
\hline & $>75$ & 12 & 54.6 & & 58.3 & & 66.7 & \\
\hline \multirow[t]{2}{*}{ RT duration } & $\leq 70$ days & 11 & 90.9 & \multirow{2}{*}{ ns } & 81.8 & \multirow{2}{*}{ ns } & 81.8 & \multirow{2}{*}{ ns } \\
\hline & $>70$ days & 176 & 76.9 & & 73.3 & & 80.3 & \\
\hline \multirow[t]{2}{*}{ Response } & $\mathrm{CR}^{\pi}$ & 166 & 84.7 & \multirow{2}{*}{0.0000} & 81.3 & \multirow{2}{*}{0.0000} & 87.1 & \multirow{2}{*}{0.0000} \\
\hline & non-CR & 21 & 20.0 & & 14.3 & & 24.6 & \\
\hline \multirow[t]{2}{*}{ Post-RT SCC } & $\leq 1.5 \mathrm{ng} / \mathrm{ml}$ & 148 & 85.6 & \multirow{2}{*}{0.0000} & 82.4 & \multirow{2}{*}{0.0000} & 86.3 & \multirow{2}{*}{0.0001} \\
\hline & $>1.5 \mathrm{ng} / \mathrm{ml}$ & 17 & 23.5 & & 23.5 & & 51.4 & \\
\hline
\end{tabular}

${ }^{*}$ Overall survival, ${ }^{\dagger}$ disease-free survival, ${ }^{\ddagger}$ pelvic disease-free survival, ${ }^{\S}$ radiation therapy, "squamous cell carcinoma antigen, ${ }^{\natural}$ complete response, ${ }^{* *}$ statistically not significant.

Table 4. Prognostic factors by multivariate analysis

\begin{tabular}{|c|c|c|c|}
\hline \multirow{2}{*}{ Factor } & \multicolumn{3}{|c|}{ Relative risk $\left(95 \% \mathrm{CI}^{*}\right)$} \\
\hline & $\mathrm{OS}^{\dagger}$ & $\mathrm{DFS}^{\ddagger}$ & $\mathrm{PDFS}^{\S}$ \\
\hline \multicolumn{4}{|l|}{ Tumor diameter } \\
\hline$\leq 4 \mathrm{~cm} \mathrm{vs}>4 \mathrm{~cm}$ & $2.293(1.146 \sim 4.587)$ & $3.141(1.653 \sim 5.969)$ & $\mathrm{ns}^{* *}$ \\
\hline $\begin{array}{l}\text { Pre-RT }{ }^{\|} \text {hemoglobin } \\
\leq 12 \mathrm{~g} / \mathrm{dl} \text { vs more }\end{array}$ & ns & ns & $0.461(0.221 \sim 0.962)$ \\
\hline $\begin{array}{l}\text { Age } \\
\leq 50 \text { years vs older }\end{array}$ & $0.468(0.228 \sim 0.961)$ & ns & ns \\
\hline $\begin{array}{l}\text { Response } \\
\mathrm{CR}^{\mathbb{\pi}} \text { vs non-CR }\end{array}$ & $7.426(3.693 \sim 14.931)$ & $6.887(3.626 \sim 13.081)$ & $6.832(3.192 \sim 14.620)$ \\
\hline
\end{tabular}

${ }^{*}$ Confidence interval, ${ }^{\dagger}$ overall survival, ${ }^{\ddagger}$ disease-free survival, ${ }^{\S}$ pelvic disease-free survival, "radiation therapy, "complete response, **statistically not significant 


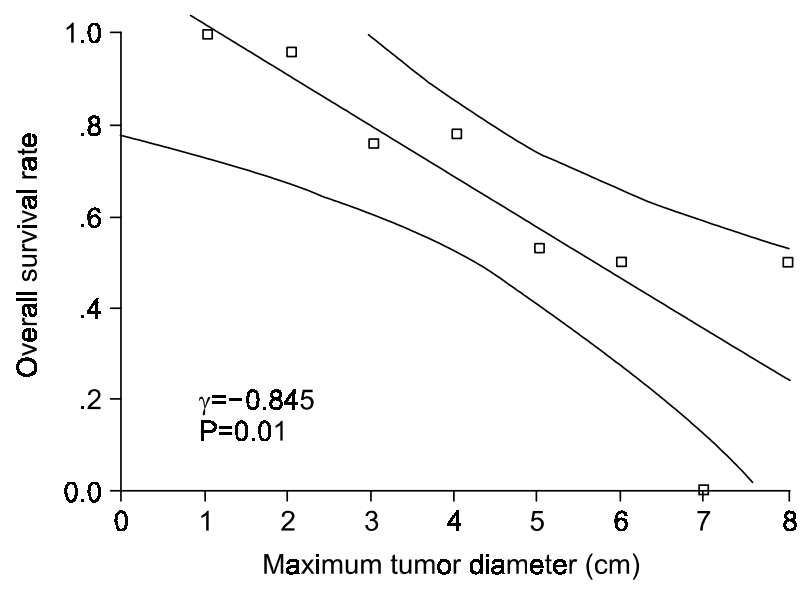

Fig. 2. 5-year overall survival rate as a function of tumor diameter for all patients. A linear regression line is fitted to the data points and two curves represent the $95 \%$ confidence limits. Survival rate had significantly negative correlation with increasing tumor diameter.

Table 5. Patterns of late complications

\begin{tabular}{llr}
\hline Grade & & No of patients (\%) \\
\hline \multirow{2}{*}{ Grade 3} & Cystitis & $13(7.0)$ \\
& Proctitis & $8(4.3)$ \\
Grade 4 & Vesicovaginal fistula & $2(1.1)$ \\
& Rectovaginal fistula & $2(1.1)$ \\
\hline
\end{tabular}

$\mathrm{A}$ 점의 총방사선량, 종양의 완해여부 등 2 개의 치료 후 인자들 을 대상으로 분석하였다. 방사선치료 후 SCC 농도는 측정되 지 않은 증례가 많았고, 또한 이 변량은 종양의 완해여부와 강력한 상관관계를 보였기 때문에 $\left(\mathrm{p}<0.001\right.$ by $x^{2}$-test), 치료 후 SCC 농도에 대한 변량은 제외하여 분석하였다. 5 년 생 존율에 영향을 미치는 유의한 인자들로서 종양의 크기, 종 양의 완해여부, 연령 등이었다(Table 4). 종양의 크기를 1 $\mathrm{cm}$ 단위로 분류하여 5년 생존율과의 상관분석에서도 통계 적으로 유의한 음의 상관관계를 보였다(Pearson correlation coefficient: -0.846, p=0.008, Fig. 2). 무병생존율에 영향을 미치는 인자로서는 종양의 크기, 종양의 완해여부이었다. 골반제어율에 영향을 미치는 인자로서는 치료 전 혈색소의 농도(Fig. 3)와 종양의 완해여부이었다.

\section{4) 만기합병증의 발생양상}

방광 및 직장의 grade 3 합병증의 발생은 각각 13 예 (7.0\%), 8예(4.3\%)이었고, grade 4 합병증의 발생은 방광질누 공이 2예(1.1\%), 직장질누공이 2예(1.1\%)이었다(Table 5). 방 광 및 직장 합병증의 5 년 누적 발생률은 각각 $9.8 \%, 5.9 \%$ 이

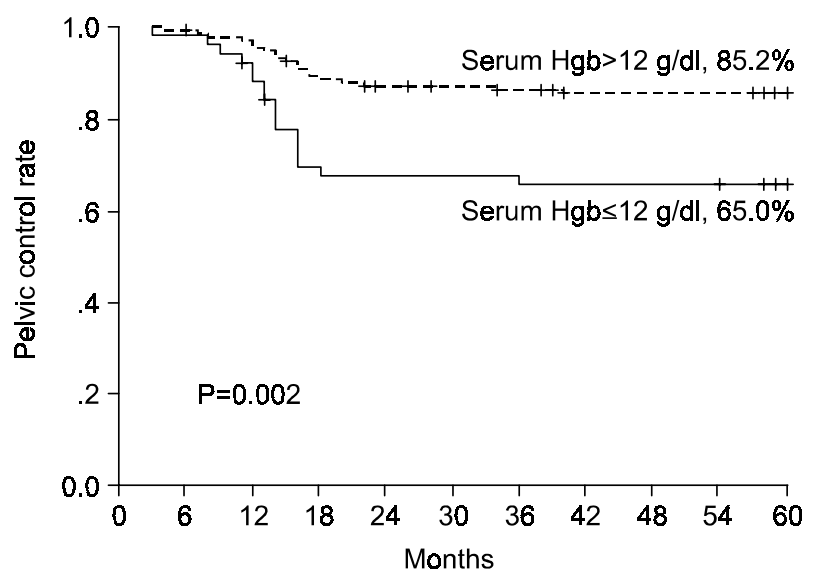

Fig. 3. 5-year pelvic control rate according to the pre-radiotherapy serum hemoglobin level. The pelvic control rate of patients with serum hemoglobin level of more than $12 \mathrm{~g} / \mathrm{dl}$ was significantly higher than that of less than $12 \mathrm{~g} / \mathrm{dl}$.

었다. 방광 합병증의 발생시점은 4 개월에서 60 개월이었고 중앙값은 33 개월이었다. 직장 합병증의 발생은 11 개월에서 26 개월로 중앙값은 17 개월이었다.

\section{고 찰}

자궁경부암의 방사선단독치료로 생존율과 골반제어율에 대한 본 연구의 결과는 타문헌의 결과와 유사하였다(9 12). 전체 생존율과 무병생존율 및 골반제어율 모두에게 영 향을 미치는 독립된 예후인자로서 방사선 치료 후 종양의 완해여부만이 다변량분석에서 유일한 인자로 나타났다. 이 는 방사선치료에 대한 종양의 반응정도가 국소 종양의 제 어여부에 가장 강력한 변수이고 궁극적으로 생존율에까지 영향을 미치는 것으로 생각된다. 본 연구에서 종양의 최대 직경은 5년 생존율과 무병생존율에 영향을 미치는 또 다른 독립된 예후인자로 나타났다. 종양의 크기는 골반제어율, 림프절 전이율, 생존율과 관계 있는 것으로 잘 알려져 있다 (10,13 15). 본 연구에서 종양의 최대 직경을 $1 \mathrm{~cm}$ 단위로 분류한 8 개 군의 생존율과 무병생존율 역시 유의한 차이를 보였고 종양의 크기가 클수록 생존율이 감소하는 선형관계 를 보였다. Stehman등(16) 역시 $1 \mathrm{~cm}$ 단위의 종양의 크기와 무병생존율 및 생존율이 선형관계이었음을 보고하였다. Hoskins등(13)은 병기 IB와 IIA의 자궁경부암에서 근치적 자궁적출술의 결과에 관한 여러 문헌을 검토하였는데, 종 양의 직경을 $4 \mathrm{~cm}$ 으로 분류한 두군에서 림프절 전이율과 생존율이 큰 차이를 보였다고 하였다. 본 연구에서도 종양 의 크기를 $4 \mathrm{~cm}$ 을 기준으로 한 두군 $(\leq 4 \mathrm{~cm} \mathrm{vs}>4 \mathrm{~cm})$ 의 방사선학적 림프절전이율은 각각 $16 / 139(11.5 \%)$ 대 7/28 
(25.0\%)로 경계적으로 유의한 차이를 보였다 $(\mathrm{p}=0.06$ by Fisher's exact test). 또한 두 군에서의 원격전이의 발생을 비 교해보면 12/140 (8.6\%) 대 8/28 (28.6\%)로 유의한 차이를 보 였다(p=0.007 Fisher's exact test). 따라서 종양의 크기가 궁극 적으로 이들 생존율에 영향을 미치는 기전은 림프절 전이 와 원격전이의 발생 등과 연관이 있을 것으로 생각된다.

한편 본 연구에서는 종양의 크기가 골반제어율에는 일변 량 분석에서 통계적으로 경계적인 유의성을 보였으나 다변 량분석에서는 유의성이 사라졌다. 종양의 최대직경을 $1 \mathrm{~cm}$ 단위로 분류하여 8 개 군의 골반제어율을 비교하였으나 종 양의 크기에 따른 골반제어율의 선형관계는 없었다. Eifel 등(14)은 병기 $\mathrm{IB}$ 의 환자에서 $5 \mathrm{~cm}$ 미만의 종양과 $5 \sim 7 \mathrm{~cm}$ 사이의 외장성 종양에 대한 방사선치료 후 중심재발률은 각각 $1 \sim 2 \%$ 이하, $3 \%$ 정도로 낮게 보고하였다. 그러나 이 들은 $6 \mathrm{~cm}$ 이상의 자궁경 내 종양에서는 강내조사의 방사 선량에 따라 골반제어율이 차이가 있다고 하였고, Perez등 (17) 역시 $5 \mathrm{~cm}$ 이상의 통형(barrel type)에서 A점의 총방사 선량에 따라 중심재발률에 차이가 있다고 하였다. 그러나 본 연구에서는 종양의 크기가 $4 \mathrm{~cm}$ 초과인 환자 28 명에서 $\mathrm{A}$ 점의 총방사선량은 $65.6 \sim 84.6 \mathrm{~Gy}$ (평균; $71.2 \mathrm{~Gy}$ )로서 이 들 방사선량에 따른 골반제어율의 유의한 차이는 없었다.

본 연구에서 종양의 완해여부 이외에 골반제어율에 영향 을 미치는 또 다른 인자로서 치료 전 혈색소의 농도가 유의 하였다. 치료 전 혈색소의 농도가 국소 재발에 독립된 예후 인자로서와 치료 전 수혈이 꼭 필요한가에 대해선 아직도 논란이 있다(18,19). Bush등(20)은 국소적으로 진행된 병기 의 환자를 대상으로 한 후향적 분석에서 혈색소의 농도가 국소 종양의 재발에 유의한 예후인자라고 보고하였고, Mendenhall등(21)은 병기와 종양의 크기를 감안하여도 적혈 구 용적이 국소 종양의 제어에 유의한 독립된 인자라고 보 고하였다. 한편 본 연구에서는 치료 전 혈색소의 농도와 종 양의 크기는 음의 상관관계를 보여 종양이 클수록 혈색소 의 농도는 낮았다(Pearson correlation coefficient; -0.289, p $<0.001)$. 혈색소의 농도를 $12 \mathrm{~g} / \mathrm{dl}$ 를 기준으로 분류한 두 군 $(\leq 12 \mathrm{~g} / \mathrm{dl} \mathrm{vs}>12 \mathrm{~g} / \mathrm{dl})$ 에서의 종양의 평균 크기에서도 4.2 $\mathrm{cm}$ 대 $3.6 \mathrm{~cm}$ 으로 유의한 차이가 있었다 $(\mathrm{p}=0.003$ by Student t-test). 혈색소의 인자를 $1 \mathrm{~g} / \mathrm{dl}$ 단위의 연속변수로 간주하여 골반제어율에 대한 다변량분석을 시행한 결과 이의 유의성 은 사라지고 종양의 완해여부만이 유일하게 남았다. 이는 혈색소의 농도와 종양의 제어율이 서로 선형관계가 있다 고 하기보다는 종양의 제어를 위해서 일정수준 이상의 혈 색소의 농도가 필요함을 의미하며 본 연구에서는 그 기준 점이 $12 \mathrm{~g} / \mathrm{dl}$ 로 나타났다. 또한 혈색소의 농도 $(\leq 12 \mathrm{~g} / \mathrm{dl} \mathrm{vs}$ $>12 \mathrm{~g} / \mathrm{dl})$ 에 따른 종양의 완해율은 각각 $39 / 50$ (78.0\%) 대
121/131 (92.4\%)로 유의한 차이가 있었다( $\mathrm{p}=0.007$ by Pearson's $x^{2}$-test). 따라서 방사선치료에서 치료 전 혈색소의 농도는 자궁경부암의 방사선치료반응과 종양제어에 중요한 생물 학적 인자로 생각된다. 그러나 수혈을 시행한 환자는 단 지 3명뿐으로 본 연구에서 수혈의 유의성은 검증할 수 없 었다.

연령과 골반제어율 또는 생존율과의 연관성에 대하여는 아직도 논란이 있다 $(9,22)$. 본 연구에서는 다변량분석상 5 년 생존율에 대해서만 유의성을 보였고 무병생존율 및 골반제 어율에는 유의성을 보이지 않았다. FIGO 병기 IB1, IB2, IIA, IIB, IIIA, IIIB, IVA의 평균연령은 각각 $60,61,60,59$, $71,57,50$ 세로 IIIB와 IVA에서 연령이 낮은 경향을 보였으 나 통계적으로 유의한 차이는 없었다( $\mathrm{p}=0.14$ by ANOVA). 본 연구로서는 연령에 대한 유의성을 충분히 설명하기에는 어려운 점이 있으며 향후 이에 대한 추가적인 분석이 요망 된다.

방사선치료 후 만기합병증의 발생에 있어서 grade 3, 4 합 병증의 발생률은 대체로 $3 \sim 15 \%$ 로 보고되고 있으며 대부 분 직장과 방광의 합병증이 주를 이룬다 $(23 \sim 25)$. 본 연구 에서는 방광과 직장합병증의 5년 누적발생률이 각각 $9.8 \%$, $5.9 \%$ 로 타문헌의 결과와 유사하였다. 본 연구에서 방광합 병증의 중앙 발생시점은 33 개월이었고 직장합병증은 17 개 월로 직장합병증 발생의 $90 \%$ 가 2년 내에 발생하였다. 문헌 에서도 직장 등의 소화기계의 합병증이 요로계보다 더 일 찍 발생하는 것으로 알려져 있다(24).

최근 방사선 치료성적을 높이기 위한 시도로 재발의 고 위험군이나 진행된 병기의 환자를 대상으로 동시적 항암화 학 방사선요법이 널리 시행되고 있다(3 6). 이러한 항함화 학제로 방사선민감제로서의 역할과 미세 원격전이의 제어 를 기대할 수 있으나 적극적인 동시적 항암화학방사선요법 은 이로 인한 잠재적인 합병증 증가의 가능성이 있어 이러 한 치료의 적응증을 분명하게 규정할 필요가 있다. 지금까 지 보고된 무작위 전향적 연구들은 대개 종양의 크기가 $4 \mathrm{~cm}$ 또는 $5 \mathrm{~cm}$ 이상이거나 FIGO 병기 IIB 이상, 골반림프 절전이 양성 등의 경우를 대상으로 하였다. 이 중 방사선단 독치료를 대조군으로 한 보고는 RTOG 90-01이 유일한 연 구이며 방사선치료와 $\mathrm{CDDP}$ 와 5-FU와의 병용요법으로 생 존율과 종양제어율의 유의한 상승을 보고하였다(6).

\section{결 론}

방사선 단독치료의 결과 종양의 완해여부와 종양의 크기 가 생존율에 영향을 미치는 유의한 인자로 나타나 특히 종 양의 직경이 $4 \mathrm{~cm}$ 초과인 경우엔 동시적 항암화학 방사선 
요법 등 보다 적극적인 치료가 고려되어야 할 것으로 생각 한다. 또한 골반제어율의 상승을 위해 혈중 혈색소의 농도 를 일정수준 이상으로 유지하는 것이 중요하다고 생각한다.

\section{REFERENCES}

1. Logsdon MD, Eifel PJ. FIGO IIIB squamous cell carcinoma of the cervix: an analysis of prognostic factors emphasizing the balance between external beam and intracavitary radiation therapy. Int J Radiat Oncol Biol Phys 1999;43(4):763-775.

2. Teshima T, Toshihiko I, Ikeda H, Miyata $Y$, Nishiyama $K$, Inoue $\mathrm{T}$, Murayama $\mathrm{S}$, Yamasaki $\mathrm{H}$, Kozuka $\mathrm{T}$. High-dose rate and low-dose rate intracavitary therapy for carcinoma of the uterine cervix. Cancer 1993;72(8):2410-2414.

3. Whitney CW, Sause W, Bundy BN, Malfetano JH, Hannigan EV, Fowler WC Jr, Clarke-Pearson DL, Liao SY. Randomized comparison of fluorouracil plus cisplatin versus hydroxyurea as an adjunct to radiation therapy in stage IIB-IVA carcinoma of the cervix with negative para-aortic lymph nodes: a Gynecologic Oncology Group and Southwest Oncology Group study. J Clin Oncol 1999;17(5):1339-1348.

4. Rose PG, Bundy BN, Watkins EB, Thigpen JT, Deppe G, Maiman MA, Clarke-Pearson DL, Insalaco S. Concurrent cisplatinbased radiotherapy and chemotherapy for locally advanced cervical cancer. New Engl J Med 1999;340(15):1144-1153.

5. Keys HM, Bundy BN, Stehman FB, Muderspach LI, Chafe WE, Suggs CL 3rd, Walker JL, Gersell D. Cisplatin, radiation, and adjuvant hysterectomy compared with radiation and adjuvant hysterectomy for bulky stage IB cervical carcinoma. New Engl J Med 1999;340(15):1154-1161.

6. Morris M, Eifel PJ, Lu J, Grigsby PW, Levenback C, Stevens RE, Rotman M, Gershenson DM, Mutch DG. Pelvic radiation with concurrent chemotherapy compared with pelvic and paraaortic radiation for high-risk cervical cancer. New Engl J Med 1999;340(15):1137-1143.

7. American Joint Commission for the Staging of Cancer. In: Manual for staging of cancer. 5th ed. Philadelphia: Lippincott, 1997; 189-194.

8. Cox JD, Stetz J, Pajak TF. Toxicity criteria of the radiation therapy oncology goup (RTOG) and the European organization for research and treatment of cancer (EORTC). Int J Radiat Oncol Biol Phys 1995;31(5):1341-1346.

9. Ha SW, Oh DH, Kim MS, Shin KH, Kim JS, Lee MS, Yoo KY. Pretreatment prognostic factors in carcinoma of the uterine cervix. J Korean Soc Ther Radiol 1993;11(2):387-395.

10. Kim OB, Choi TJ, Kim JH, Lee HJ, Kim YA, Suh YW, Lee TS, Cha SD. Carcinoma of uterine cervix treated with high dose rate intracavitary irradiation: 1 . patterns of failure. J Korean Soc Ther Radiol 1993;11(2):369-376.

11. Suh CO, Kim GE, Loh JJK. Treatment of carcinoma of the uterine cervix with high-dose-rate intracavitary irradiation using Ralstron. J Korean Soc Ther Radiol 1990;8(2):231-239.
12. Ahn SJ, Chung WK, Nah BS, Nam TK, Choi HS, Byun JS. Irradiation alone in stage IB, IIA and IIB cervix cancer: 2 correlation between treatment factors and pelvic tumor control. J Korean Cancer Assoc 1998;30(2):321-328.

13. Hoskins WJ. Prognostic factors for risk of recurrence in stage Ib and IIa cervix cancer. Bailliere's Clin Obstet Gynecol 1988;2:817-828.

14. Eifel PJ, Morris M, Wharton JT, Oswald MJ. The influence of tumor size and morphology on the outcome of patients with FIGO stage IB squamous cell carcinoma of the uterine cervix. Int J Radiat Oncol Biol Phys 1994;29:9-16.

15. Alvarez RD, Potter ME, Soong SJ, Gay FL, Hatch KD, Partridge EE, Shingleton HM. Rationale for using pathologic tumor dimensions and nodal status to subclassify surgically treated stage IB cervical cancer patients. Gynecol Oncol 1991; 43:108-112.

16. Stehman FB, Bundy BN, Disaia PJ, Keys HM, Larson JE, Fowler WC. Carcinoma of the uterine cervix treated with radiation therapy 1: a multi-variate analysis of prognostic variables in the Gynecologic Oncologic Group. Cancer 1991; 67:2776-2785.

17. Perez CA, Kao MS. Radiation therapy alone or combined with surgery in the treatment of barrel-shaped carcinoma of the uterine cervix (stage IB, IIA, IIB). Int J Radiat Oncol Biol Phys 1985;11:1903-1909.

18. Eisenkop S, Spirtos N, Montag T, Moossazadeh J, Warren P, Hendrickson M. The clinical significance of blood transfusion at the time of radical hysterectomy. Obstet Gynecol 1990; 76:110-113.

19. Hirst D. Anemia: a problem or an opportunity in radiotherapy? Int J Radiat Oncol Biol Phys 1986;12:2009-2017.

20. Bush R. The significance of anemia in clinical radiation therapy. Int J Radiat Oncol Biol Phys 1986;12:2047-2050.

21. Mendenhall WM, Thar TL, Bova FJ, Marcus RB Jr, Morgan LS, Million RR. Prognostic and treatment factors affecting pelvic control of stage IB and IIA-B carcinoma of the intact uterine cervix treated with radiation therapy alone. Cancer 1984;53:2649-2654.

22. Dattoli, Gretz HF, Beller U, Lerch IA, Demopoulos RI, Beckman EM, Fried PR. Analysis of multiple prognostic factors in patients with stage IB cervical cancer: age as a major determinant. Int J Radiat Oncol Biol Phys 1989;17:41-47.

23. Pourquier H, Dubois JB, Delard R. Cancer of the uterine cervix: dosimetric guidelines for prevention of late rectal and rectosigmoid complications as a result of radiotherapeutic treatment. Int J Radiat Oncol Biol Phys 1982;8(11):1887-1895.

24. Pedersen D, Bentzen SM, Overgaard J. Early and late radiotherapeutic morbidity in 442 consecutive patients with locally advanced carcinoma of the uterine cervix. Int J Radiat Oncol Biol Phys 1994;29:941-952.

25. Perez CA, Breaux S, Bedwinek JM, Madoc-Jones H, Camel HM, Purdy JA, Walz BJ. Radiation therapy alone in the treatment of carcinoma of the uterine cervix. II. Analysis of complications. Cancer 1984;54(2):235-246. 